Volume: 13 Issue: 3 Year: 2016

\title{
Development of The Well- Star Scale
}

\section{İyilik Hali Yıldızı Ölçeği'nin geliştirilmesi}

\author{
Fidan Korkut Owen ${ }^{1}$ \\ Türkan Doğan ${ }^{2}$ \\ Nur Demirbaş Çelikk \\ Dean W. Owen ${ }^{4}$
}

\begin{abstract}
Özet

Various models of wellness have appeared in the literature and had common themes including choice, process, life-style, and characteristics of healthy individuals. The Well-Star model was developed for use with a Turkish population and the work described in this article documents the development of an assessment instrument for wellness according to The Well-Star model. After a review of the literature an item pool was established and after taking feedback from four counselor educators, this item pool was reduced to items. The participants in this investigation were 545 university students representing three separate groups. The first group was composed of 291 and data were collected for the purpose of performing an exploratory factor analysis. The second group's data was used to perform a confirmatory factor analysis $(\mathrm{N}=156)$. The final group of 98 provided data that permitted assessment of concurrent validity and reliability. After Exploratory factor analysis 24 items and five dimensions emerged. Confirmatory factor analysis was performed to test goodness of fit whether the factor structure was acceptable. In an attempt to establish criterion related validity (concurrent type) the results of the Well-Star and the results of Health Promoting Lifestyle II (Walker \& Hill-Polerecky, 1996) which was adapted for Turkish by Bahar, Beşer, Gördes,

İyilik haliyle ilgili modellerin ortaklıkları iyilik halinin bir seçim, süreç, yaşam biçimi olduğunu ve sağlıklı insanların özelliklerini göstermesidir. Bu çalışmada, iyilik hali yıldızı modeline dayalı olarak üniversite öğrencileri için bir ölçeğin geliştirilmesi ile ilgili yapılan psikometrik çalışmalar verilmiştir. Madde yazım hazırlıkları sonucunda madde havuzu için dört psikolojik danışman eğitimcisinden geri bildirim alınarak ölçeğin 59 maddelik uygulamaya hazır olan taslağı elde edilmiştir. Araştırmada veriler üç farklı gruptan toplam 545 üniversite öğrencisinden edinilmiştir. Açıklayıcı faktör analizi için 291 öğrenciden elde edilen veriler kullanılmıştır Yapılan analizleri sonucunda 24 maddeli ve beş boyutlu ölçek elde edilmiş ve 156 öğrenciye uygulanarak doğrulayıcı faktör analizi yapılmıştır. Yapılan analiz sonucunda modelin doğrulandığı sonucuna ulaşılmıştır Buna göre ölçeğe İyilik Hali Yıldızı Ölçeği (İHYÖ) adı verilmiştir. Toplam 98 öğrenci ile yapılan benzer ölçekler geçerliği için Bahar, Beşer, Gördes, Ersin ve Kissal, (2008) tarafindan Türkçe'ye uyarlanan Sağlıklı Yaşam Biçimi Davranışları Ölçeği II kullanılmış ve İHYÖ ile korelasyonu 0.76 bulunmuştur. Yapilan güvenirlik çalışmalarında ölçeğin toplamı için içtutarlık katsayısı $\mathrm{r}=0.86$, alt boyutlarınkiler

\footnotetext{
${ }_{1}^{1}$ Prof. Dr., Bahçeşehir University, Educational Science Faculty, Counseling Program, fidan.korkut@es.bahcesehir.edu.tr 2 Assoc. Prof. Dr., Hacettepe University, Faculty of Education, Department of Counseling and Guidance, dogant@hacettepe.edu.tr

3 Assist. Prof. Dr., Alanya Alaaddin Keykubat University, Faculty of Education, Department of Guidance and Psychological Counseling, demirbas.nur@gmail.com

${ }^{4}$ Prof. Dr., Middle East Technical University, Northern Cyprus Campus, Faculty of Education, dean@metu.edu.tr
} 
Korkut Owen, F., Doğan, T., Demirbaş Çelik, N., \& Owen, D. W. (2016). İyilik Hali Yıldızı Ölçeği’nin geliştirilmesi. Journal of Human Sciences, 13(3), 5013-5031. doi:10.14687/ihs.v13i3.4130

Ersin and Kissal (2008) when administered were correlated $(\mathrm{r}=.76, \mathrm{p}<.0001)$ which was considered quite satisfactory. Reliability was determined by calculating Chronbach's Alpha was 0.86. Alpha values for sub-dimensions ranged from 0.57 to 0.79 . These results suggest that the instrument possesses acceptable validity and reliability. Findings were discussed according to literature.

Keywords: Wellness, metaphor; Well Star model; Well Star Scale.

(Extended English abstract is at the end of this document) ise sirasiyla $0.79 ; 0.77 ; 0.63 ; 0.57$ ve 0.71 olarak elde edilmiştir. Elde edilen sonuçları IHYÖ'nün üniversite öğrencileri için kullanilabilecek özellikte olduğunu göstermektedir.

Anahtar Kelimeler: İyilik hali; metaphor; İyilik Hali Yıldızı Modeli; İyilik Hali Yıldızı Ölçeği.

\section{Giriş}

Son yıllarda alandaki pek çok çalışma, psikolojik danı̧̧ma ve rehberlik alanının olumsuz sonuçları önlemek ile sağlık ve iyilik halini başlatmak ve sürdürmek (Cowen ve Durlak, 2000) dolayısıyla insanların iyilik hallerini artırmaya yönelik etkinliklere (Rotter, 2000) odaklanması gerektiğini vurgulamaktadır. Bu açıklamalar, psikolojik danışmanların ruh sağlı̆̆ını geliştirme ve oluşabilecek sorunları önleme ile ilgili ve danışanların iyilik hallerini artırmaya yönelik işlevlerini vurgulamaktadır. Amerikan Psikolojik Danışma Derneği delegelerinin 2010 yllında fikir birliğine vardıkları psikolojik danışma tanımında iyilik hali kavramına da yer verilmektedir (American Counseling Association, 2010). Dolayısıyla psikolojik danışmanların görevleri arasında danışanlara her türlü gelişim alanında yardımcı olmak ve iyilik hallerini artırmak da yer almaktadır. $\mathrm{Bu}$ anlamda psikolojik danışmanların, danışanların iyilik hallerini artırmak konusunda yapabileceklerini planlamadan önce ihtiyaç analizi/ danışanların hangi müdahalelere gereksinimi olduğunu ortaya koyan bazı çalışmalar yapmaları gerektiği görülmektedir. İyilik hali ile ilgili ölçme araçlarını kullanmak bu amaca hizmet eden yollardan biri olarak görülmektedir. Buradan hareketle bu çalışmanın amacı bir iyilik hali ölçeğinin geliştirilmesidir.

1.2. İyilik Hali Kavramı: Antik Yunan zamanından beri farklı biçimlerde ifade edilen iyilik hali kavramı, yeni bir kavram olmasa da psikolojik danışma alanının değişmesine paralel olarak yirminci yüzyllın ikinci yarısından sonra pek çok yayına konu olmuştur (Myers, 1992, s.136). İyilik hali kavramı 1960’lı yıllarda alternatif sağlık hareketi sırasında geçerlik sağlamıştır. Dünya Sağlık Örgütü sağllğı hastalığın olmaması hali olarak değil fiziksel, zihinsel ve sosyal tüm boyutlarda iyi oluş hali olarak ele almaktadır ve bu tanım 1958 yllından beri değiştirmemiştir (World Health Organization, 2003). Tanımda sağlı̆̆ın çok boyutlu olarak ele alındığı dikkati çekmektedir. Jayanti ve Burns (1998, s.6 ), sağlıklı davranışlar açısından bakıldığında sağlıklı olma bilincinin iyilik haline yönelik yaşam biçimi olarak ifade edildiğini belirtmektedirler. Alternatif sağlık hareketi doğrultusunda iyilik hali konusundaki ilk akademik tanım Dunn (1961) tarafından yapılmış ve ardından Ardell (1977) ve Hettler (1980) tarafindan konuyla ilgili kuramsal çerçeve oluşturmaya başlanmıştır.

O tarihten itibaren iyilik hali kavramının bir dizi farklı tanımı yapılmış ve bir dizi iyilik hali modeli geliştirilmiştir. Örneğin, Westgate'e (1996, s.26) göre iyilik hali kavramı, sağllk kavramının daha bütüncül olarak ele alınmaya başlamasına paralel olarak sağlıklı insanların işlevlerini araştırmakla ilgili bir kavrama dönüşmüştür. Ona göre, iyilik hali, bireyin duygusal ve fiziksel gereksinimlerini anlaması ve yaşam biçimini bu gereksinimleri doyurmaya yönelik olarak 
Korkut Owen, F., Doğan, T., Demirbaş Çelik, N., \& Owen, D. W. (2016). İyilik Hali Yıldızı Ölçeği’nin geliştirilmesi. Journal of Human Sciences, 13(3), 5013-5031. doi:10.14687/jhs.v13i3.4130

düzenlemesini içeren bir kendine bakma sürecidir. Corbin, Welk, Corbin ve Welk (2006) iyilik halini sağlıklı olmaktan daha öte bir yaşam biçimi olarak ele almaktadırlar.

Bir diğer tanımda iyilik hali, optimal düzeyde sağlıklı olmaya yönelmiş, beden, akıl ve ruhun bütünleştiği, bireysel olarak amaçlara sahip olma ve daha anlamlı yaşam geçirme hedefi olan, sosyal, kişisel ve ekolojik olarak tüm alanlarda işlevsel olan bir yaşam sürdürmek (Myers, Sweeney ve Witmer, 2000, s. 252) anlaminda ele alınmaktadır. Miller ve Foster (2010, s.10) yapilan tanımlarda sıklıkla iyilik halinin bir seçim, bir süreç, bir yaşam biçimi olarak ele alındığını ve sağlıklı insanların özelliklerinin temel alındığını belirtmektedirler. Bunun dışında iyilik hali tanımlarında, iyilik halinin çok boyutlu olsa da bütüncül bir yapı gösterdiği; dengeyi vurguladığ1 ve öznel yanının olduğu da (Miller ve Foster, 2010) rastlanan ortaklıklardır. Bu açıklamalara ek olarak iyilik halinin öğrenilebilir ve değiştirilebilir özelliklere sahip olduğunun ve değişim kavramı (Myers, Sweeney ve Witmer, 2000, s.258) ile yakından ilisskili olduğunun da vurgulanması gerekmektedir. Bu noktada psikolojik danışmanlanın iyilik hali modellerini bir değişim aracı olarak kullanabilecekleri görülmektedir.

1.2 İyilik Hali ile İlgili Modeller: İyilik hali ile ilgili geliştirilen biri dizi model bulunmaktadır. Çoğu iyilik hali modeli fiziksel sağlık mesleklerine dayalı iken ilk kez Sweeney ve Witmer (1991) tarafından tanımlanan ardından Myers, Sweneey ve Witmer (2000) tarafindan geliştirilen İyilik Hali Çemberi Modeli, insan gelişimi ve davranışı ile ilgili insancıl kuramlara ve çoklu disiplinlere dayalı olması ile özgündür. Bu modelde iyilik hali spiritüel/manevi, çalışma- -serbest zaman, arkadaşlık, sevgi ve kendini düzenleme biçiminde beş ana boyuttan oluşmaktadır. İyilik halini çok boyutlu olarak ele alan modelleri incelediği çalsşmalarında Roscoe (2009) toplam dokuz modelden, Miller ve Foster (2010, s.9) ise toplam on üç modelden söz etmektedir. Bu modeller içinde Türkiye'de en fazla bilinen model Myers, Sweeney ve Witmer (2000) tarafindan geliştirilen İyilik Hali Çemberi Modelidir. Sözkonusu model sonradan içerik ve yap1 olarak değiştirerek Bölünemez Ben: Kanıta Dayalı İyilik Hali Modeli adını almıştır (Myers ve Sweeney, 2004; Myers ve Sweeney, 2005). Model, beş boyutlu yapısını korumaktadır ancak bu modelde beş boyut yaratıcı, sosyal, temel (esas), başa çıkan ve fiziksel ben olarak adlandırllmaktadır. Roscoe (2009), iyilik hali modellerinde en fazla sosyal, duygusal, fiziksel, bilişsel/entellektüel ve spiritüel boyutların vurgulandığını, mesleki, psikolojik ve çevresel boyutların daha az ele alındığını ortaya koymuştur.

Türkiye’ye özgü bir iyilik hali modeli geliştirme çabalarında Korkut-Owen ve Owen (2012) ilgili alanyazındaki bu ayrımları dikkate almışlardır. Özellikle Roscoe (2009)'nun iyilik hali modellerini karşılaştırdığı çalışmasında en fazla sosyal, duygusal, fiziksel, entellektüel ve spiritüel olmak üzere beş boyutun vurgulandığını belirtmesi dikkate alınmıştır. Modelin beşli yapıda olmasına karar verilmesinin bir başka nedeni Türkçe'deki "Yıldızının parlak ya da sönük olması" benzetmesini kullanılarak yıldız metaforunun uygulamada kolaylık sağlayacağının düşünülmesidir. Beş boyutlu yıldız metaforunun düşünülmesinin diğer bir nedeni ise denizyıldızının da beş kolunun olması ve kopan kolunu yenileyebilmesidir (Bedir ve Kocabaş, 2015). İyilik hali kavramında değişim kavramı ile harekete geçme kavramları çok önemli bir yer tutmaktadır (Myers, Sweneey ve Witmer, 2000). Bireyler etkili olmadığını düşündükleri iyilik hali alanlarını daha iyi hale getirmek amaciyla harekete geçebilir ve o alanda değişim yaratabilirler. Hatta bir alandaki iyileşme diğer alanlara da yansımaktadır. Buradan yola çıkarak Korkut-Owen ve Owen (2012, s. 27) modele İyilik Hali Yıldızı Modeli (IHYYM) adını vermişler. İHYM, fiziksel, psikolojik/duygusal, sosyal, entellektüel/mesleki ve spiritüel olmak üzere beş boyuttan oluşmaktadır. Bu boyutların birbirleriyle ilişki halinde olduğu, birbirilerini etkileyebileceği düşünülmektedir. Metaforik açıklamayla her boyutun bir arada bireyin yıldızını oluşturmaktadırlar. Bu boyutların tanıtımı aşağıda verilmiştir. 
Korkut Owen, F., Doğan, T., Demirbaş Çelik, N., \& Owen, D. W. (2016). İyilik Hali Yıldızı Ölçeği’nin geliştirilmesi. Journal of Human Sciences, 13(3), 5013-5031. doi:10.14687/jhs.v13i3.4130

Firiłksel iyilik hali: Sağlıklı olmanın fiziksel yanlarına değinen bu boyut, genel olarak dengeli beslenme, fiziksel olarak aktif olma, düzenli uyku, doktor kontrolü gibi fiziksel sağlı̆ga yönelik davranışları yerine getirme gibi sağlıklı yaşam biçimine ilişkin öğeleri içermektedir. Psikolojik / Duygusal iyilik bali: Psikolojik ve duygusal iyilik halinin bir arada alınmasına karar verilirken bu iki kavramı bir arada alan iyilik hali ayrımlarının olması (Depken, 1994; Miller ve Foster, 2010) ve bu iki kavramın iç içe olması dikkate alınmıştır. Bu boyut, sağlıklı olmanın daha çok içsel deneyimlere ilgili olan boyutudur ve bireyi duyguları fark etme / kontrol edebilme, kendine, yaşam durumlarına ve çatışmalara gerçekçi, olumlu ve geliştirici olarak bakabilme gibi özellikleri içermektedir. Sosyal iyilik hali: Bireylerin diğer bireylerle, toplumla, çevreyle ve doğayla etkileşimin niteliği ve derecesini gösteren bu boyut, aile, arkadaşlar ve diğer önemli kişiler tarafindan verildiği algılanan sosyal desteği de içermektedir. Bu boyutta hemcins ve karşı cinsle sağlıklı ilişkiler de yer almaktadır. Entelektüel / mesleki iyilik hali: Mesleki iyilik halini hiç ele almayan modellerin yanı sıra (Myers ve Sweeney, 2005) bu iki boyutu ayr1 olarak (Hettler, 1980) ya da bir arada alan (Oakland University, William Beaumont School of Medicine, 2015) yaklaşımlar vardır. Bu destekten yola çıkarak bu iki boyutun bu modelde de bir arada ele alınabileceği düşünülmüştür. Bu boyutta, entellektüel olarak aktif olmayı sevme, bilgilerini kendisi ve toplum için kullanma, kendini zihinsel olarak zorlayacak etkinlikler arama, problem çözme gibi özellikler yer almaktadır. Bunun yanı sıra paralı ya da gönüllü olarak kişisel değerlerini doyuracak etkinliklerde bulunma, rolleri arasında denge kurma, becerilerini topluma katk1 için kullanma (Miller ve Foster, 2010) gibi özellikleri de içermektedir. Spiritüel iyilik hali: Spiritüel iyilik halinde yaşamın amacını ve anlamını araştırma, daha büyük bir güçle paylaştığı bağlantıları fark etme gibi özellikler vardır.

İyilik hali kavramı ve modelleri aslında yaşam biçimi davranışlarına odaklanmaktadır (Rachele, Washington, Cuddihy, Barwais ve McPhail, 2013, s. 162). Sağlıklı yaşam biçiminden kast edilen, bireylerin sağlıklarını etkileyebilecek tüm davranışlarını kontrol etmeleri, günlük etkinliklerini ona göre düzenlemeleri ve sağlıklarını daha iyi hale getirmeye yönelik davranışları uygulamalarıdır. Sağlıklı yaşam biçimi davranışları, yeterli ve dengeli beslenmeyi, stres yönetimini, düzenli egzersiz yapmayı, manevi gelişimi, kişilerarası ilişkileri ve bireyin sağlığını koruma ve geliştirmesine ilişkin sorumluluk almasını kapsamaktadır (Walker, Sechrist ve Pender, 1987, s.76). Görüldügü gibi bireylerin sağlıklı yaşam biçimine yönelik davranışlar göstermeleri, onların iyilik hallerini artırmalarınave korumalarına hizmet etmektedir.

1.3. Üniversite öğrencileri ve iyilik hali: Üniversite öğrencilerinin iyilik halleri ile ilgili yapılan çalışmalar kadın ve erkeklerin farklı alanlarda daha duyarlı olduklarını göstermektedir (DixonRayle ve Myers, 2004; Hartwig ve Myers, 2003; Schuster, Dobson, Jauregui ve Blanks, 2004). Bir çalışmada genelde kadınların iyilik hallerinin daha yüksek olduğu, sınıf düzeyi arttıkça iyilik halinin de arttı̆̆ bulunmuştur (Oleckno ve Blacconiere, 1990). Roothman, Kirsten ve Wissing de (2003) farklı cinsiyetlerin iyilik hallerinin farklı alanlarda birbirinden farklılaştığını, örneğin erkeklerin fiziksel, kadınların spiritüel iyilik hallerinin daha yüksek olduğunu belirtmektedirler. Hermon ve Davis (2004) beklenen üniversite yaşlarındaki öğrencilerle daha ileri yaşlardaki üniversite öğrencileri ile yaptıkları çalışmada iki grup arasında iyilik hali ölçeğinin gerçekçi inançlar, kontrol duygusu, fiziksel etkinlik ve kendine bakma alt boyutları açısından farklar olduğunu saptamışlardır. Myers ve Mobley da (2004) üniversite öğrencilerinin iyilik hallerinin yetişkinlerden daha az düzeyde olduğunu bulmuşlardır.

Üniversite öğrencilerinin iyilik halleri ile ilgili yapılan yurtdış çalışmaların bazılarının yaşam biçimine ya da sağlıklı davranışlara odaklandığ görülmektedir. Sidman, D’Abundo ve Hritz (2009) tarafindan yapılan çalışmada üniversite öğrencilerinin fiziksel hareketle ilgili öz yeterlik algılarının, algilanan toplam iyilik halini ve fiziksel, spiritual/manevi, entellektüel, psikolojik ve duygusal iyilik hali alt boyutlarını yordadığı sadece sosyal boyutu yordamadığı bulunmuştur. Lee 
Korkut Owen, F., Doğan, T., Demirbaş Çelik, N., \& Owen, D. W. (2016). İyilik Hali Yıldızı Ölçeği’nin geliştirilmesi. Journal of Human Sciences, 13(3), 5013-5031. doi:10.14687/jhs.v13i3.4130

ve Yuen-Loke (2005) Hong Kong'daki üniversite öğrencileriyle yaptıkları çalısmada sağlıklı yaşam stili profili ile ilgili çalışmışlardır. Araştırma sonucunda cinsiyetler arasında sağlık sorumluluğu, beslenme alışkanlıkları, spiritüel büyüme, kişilerarası ilişkiler ve stresle başa çıkma konusunda fark bulamamışlar ancak erkeklerin fiziksel olarak aktif olmada daha iyi durumda olduğunu saptamışlardır. Laska, Pasch, Lust, Story ve Ehlinger (2009) tarafindan iki binden fazla üniversite öğrencisiyle yapılan yaşam biçimine ilişkin araştırmada kadın ve erkeklere yönelik farklı sonuçlar elde edilmiştir. Çalışma sonunda kadınların \% 28'nin, erkeklerin ise \% 33.6'sının madde kullanımı, alkollü iken araba kullanma, kötü beslenme, yetersiz uyuma konusunda yüksek risk gösterdiklerini saptamışlardır. Bu çalışmalar beliren yetişkinlik döneminde olan üniversite öğrencilerinin bir dizi gelişimsel sorunla beraber sağlıklı yaşam becerilerini ve alışkanlıklarını edinmede de zorluk yaşadıklarını göstermektedir.

Türkiye'de üniversite öğrencileri ile yapılan iyilik hali ile ilgili sınırlı sayıda çalışma bulunmaktadır. Bu araştırmaların birisinde Doğan (2006a) ailelerinden ve arkadaşlarından yeterince destek gören, fiziksel egzersiz yapan ve kendi geleceklerine ilişkin olumlu düşüncelere sahip üniversite öğrencilerinin genel iyilik halinin daha yüksek olduğunu saptamıştır. Genel iyilik halinin incelendiği araştırmaların yanı sıra iyilik halinin boyutlarını etkileyen faktörlerin incelendiği çalısmalar da bulunmaktadır. Örneğin, Doğan ve Yıldırım (2006) üniversite öğrencilerinin iyilik halinin arkadaşl1k ve sevgi boyutlarını etkileyen faktörleri inceledikleri araştırmalarının sonucunda; kız öğrencilerin erkek öğrencilere kıyasla arkadaşlık ve sevgi boyutlarında; karşı cinsten bir arkadaşı olan öğrencilerin olmayanlara klyasla sevgi boyutunda iyilik hallerinin daha yüksek olduğunu ortaya koymuşlardır. Bir diğer çalışmasında Doğan (2006b), erkek öğrencilerin serbest zaman puan ortalamalarının kız ögrencilerin puan ortalamalarından yüksek olduğunu; egzersiz yapma sıklı̆̆ı artıkça her iki boyutta da bir artma olduğunu belirlemiştir. Ayrıca öğrencilerin gelecekle ilgili düşünceleri olumluya doğru gittikçe iyilik halinin maneviyat alt ölçek puan ortalamalarının yükseldiği görülmüştür. Psikolojik belirtilerin yordayıcısı olarak iyilik halini incelendiği bir diğer çalışmada ise, somatizasyon belirtilerini en iyi yordayan iyilik hali boyutlarının sırasıyla kendini yönetme ve sevgi olduğu saptanmıştır. Depresyon, Anksiyete ve Öfke/saldırganlık belirtilerini de kendini yönetme boyutu anlamlı olarak yordamaktadır (Doğan, 2008). Kasapoğlu (2014) tarafından yapılan çalışmada üniversite öğrencilerin cinsiyetlerine göre iyilik hali düzeylerinde bir farklılık bulunmazken; son sınıf öğrencilerinin iyilik halinin diğer sınıflarda okuyan öğrencilere göre daha yüksek olduğu saptanmıştır. Oğuz-Duran (2006), çalışmasında sanat etkinlikleriyle zenginleştirilmiş iyilik hali grupla psikolojik danışma programının üniversite öğrencilerinin iyilik hali üzerindeki etkisi incelemiştir. Deneysel çalışmanın sonuçları programın üniversite öğrencilerin genel iyilik hali ile iyilik halinin bilişsel-duygusal ve yaşam hedefleri boyutları üzerinde olumlu etkileri olduğunu göstermiştir. Sarı (2003) tarafindan yapılan çalışmada bulgular, iyilik halini farklı boyutlarında cinsiyetler ve not ortalamaları yüksek ve düşük olanlar arasında fark olduğunu göstermektedir.

İyilik hali kavramı ile sağlığın boyutlarına ilişkin yapılan bazı ayrımlarının çok benzer olduğu görülmektedir. Şöyle ki sağlığın fiziksel, zihinsel, duygusal, sosyal ve manevi sağlık, (Tripp ve Stachowiak, 1992, s.156) olarak gruplandığına bakıldığında iyilik haliyle benzer gruplamanın olduğu görülmektedir. $\mathrm{O}$ nedenle bu araştırmada üniversite öğrencileriyle yapılan sağlıklı yaşam biçimi kavramları ile ilgili çalışmalar da araştırılmıstır. İlhan, Bahadırlı ve Ercan-Toptaner (2014) tarafindan yapılan çalısmada hemşirelik bölümü öğrencilerinin, ikinci sınıf öğrencilerinin, kadınların, yurtta kalanların, annesi ilkokul veya üniversite mezunu olan öğrencilerin Sağlıklı Yaşam Biçimi Davranışları Ölçeği (SYBDÖ) toplam puanları, diğer gruplara göre yüksek bulunmuştur. Yüksel (2012) tarafindan yapılan araştırmada elde edilen bulgulara göre; üniversite öğrencilerin sağlı̆̆ geliştirici yaşam biçimi davranışları orta düzeydedir. Öğrencilerin üniversitede geçirdikleri yıl arttıkça sağlığı geliştirici yaşam biçimi davranışları olumsuz biçimde etkilenmektedir. Ayrıca, sağlık davranışı cinsiyet, sosyoekonomik düzey ve annenin eğitim durumundan 
etkilenmektedir. Üniversite öğrencileriyle yapılan bir diğer çalışmada Tambağ (2011) genel olarak sağlıklı yaşam biçimi davranışları açısından kız ve erkek öğrenciler arasında beslenme, sağllk sorumluluğu ve egzersiz alt ölçekleri açısından farklar bulmuştur. Gültekin ve İrgil (2001) tıp fakültesi ögrencilerinin sosyal aktivitelere katılımı ve sağlıkla ilgili davranışlarını değerlendirmek amacıyla yaptıkları çalışmada öğrencilerin çoğunluğunun sosyal aktivitelere katılmadığı ve çoğunlukla kendi sağlıklarını önemsemediklerini saptanmışlardır. Başka bir çalışmada İlhan, Batmaz ve Utaş-Akhan (2010) tarafindan farklı fakültelerdeki öğrencilere SYBDÖ uygulanmıştır. Sonuçta kız öğrencilerin sağlık sorumluluğu alt grubu puan ortalaması, erkeklere göre, hemşirelik bölümünde okuyan öğrencilerin sağlık sorumluluğu ve beslenme alt grubu puan ortalaması diğer bölümlere göre, son sinıf öğrencilerinin SYBDÖ puan ortalaması diğer sinıflara göre, evli olanların kendini gerçekleştirme ve beslenme alt grubu puan ortalaması, bekarlara göre, ekonomik durumu çok iyi olanların SYBDÖ puan ortalaması, ekonomik durumu orta ve iyi olanlara göre istatistiksel açıdan anlamlı derecede yüksek bulunmuştur.

Yapılan bu çalışmalar üniversite öğrencilerinin daha sağlıklı olabilmeleri ve iyilik hallerini artırmaları için çalışmalar yapılması gerektiğine işaret etmektedir. Bunun yollarından birisi de üniversite öğrencilerinin iyilik hallerinin hangi düzeyde olduğunun saptanması ve ona göre hangi alanlara yönelik olarak çalışma yapılması gerektiğini ortaya koymaktır. Bu amaçla iyilik halini ölçmeye yönelik olarak geliştirilen bazı ölçme araçları bulunmaktadır.

1.4 İyilik Hali ile İlgili Ölçme Araçları: İyilik halini ölçmekle ilgili benimsenen tanıma ya da dayandığı modele göre farklı odakları olan bir dizi ölçek vardır. Ölçeklere örnek olarak Beş Faktörlü İyilik Hali Ölçeği (Myers ve Sweeney, 2004), Ergen İyilik Hali ve Sağllk Anketi (Steiner, Pavelski, Pitts ve McQuivey, 1998), Alg1lanan İyilik Hali Anketi (Adams, Bezner ve Steinhardt, 1997) ve Laffrey Sağlık Kavramı Ölçeğinin İyilik Hali Faktörü (Yarcheski, Mahon ve Yarcheski, 2005) verilebilir.

Türkiye'de iyilik hali ile ilgili ölçme araçları daha çok uyarlama çalışmaları biçimindedir. Myers ve Sweeney’in (2000) Beş Faktörlü İyilik Hali Ölçeği'nin üniversite gençleri için olan versiyonu Doğan (2004), 6.-9. sinıflar için olan versiyonu ise Korkut-Owen ve Öğretmen (2013) tarafindan Türkçe'ye uyarlanmıştır. İyilik hali ile ilgili olmasına rağmen farklı adlarla uyarlanan ölçeklere de rastlanmaktadır. Örneğin Adams, Bezner ve Steinhardt (1997) tarafindan geliştirilen perceived wellness ile ilgili ölçek Memnun (2006) tarafindan Türkçe'ye Esenlik Ölçeği adıyla uyarlanmıştır. İlgili alan yazınında, iyilik hali kavramının yanısıra iyi oluş (well-being) kavramının da kullanıldığı görülmektedir. Her iki kavram da bireydeki olumlu işlevselliğe dikkat çekmekle birlikte iyi oluş bireyin yaşamına ilişkin öznel yargılarla ilişkiliyken iyilik hali bireyin sürdürdüğü yaşam biçimi ile ilisskilidir ve daha geniş bir kavramdır. Öte yandan iyi oluş ile ilgili olmalarına rağmen iyilik hali olarak ele alınan ölçek uyarlama çalışmalarına da rastlanmaktadır. Örneğin Diener ve arkadaşları (2010) tarafindan geliştirilen ve Flourishing Scale olarak anılan sekiz maddelik iyi oluş ile ilgili ölçek Türkçe'ye Fidan ve Usta (2013) tarafindan İyilik Hali Ölçeği adı altında uyarlanmıştır.

Türkiye'de iyilik haliyle ilgili geliştirilen tek ölçme aracı olarak Güneri (2003) tarafindan geliştirilen İyilik Hali Envanteri'ne rastlanmıştır. Söz konusu ölçek daha sonra Oğuz Duran (2006) tarafindan kısaltılarak dört boyutlu 30 maddelik bir hale getirilmiş ve İyilik Hali Envanteri Kısa Formu adını almıştır. Bununla birlikte, kültürümüze uygun bu konuya dayanan farklı model ve ölçme araçlarına ihtiyaç bulunmaktadır. Bu amaçla İyilik Hali Yıldızı Modeli’ni temel alarak üniversite öğrencilerine ve yetişkinlere yönelik yeni bir ölçek geliştirme çalışmasına başlanmıştır. Böylece bu ölçeğin gerçekleştirilecek iyilik hali ile ilgili çalışmalardan önce durum saptama ve yapılan müdahelelerinin etkililiğini belirlemede kullanılabileceği umulmaktadır. 
Korkut Owen, F., Doğan, T., Demirbaş Çelik, N., \& Owen, D. W. (2016). İyilik Hali Yıldızı Ölçeği’nin geliştirilmesi. Journal of Human Sciences, 13(3), 5013-5031. doi:10.14687/jhs.v13i3.4130

\section{Yöntem}

\section{1. Araştırmaya katılan bireyler}

Bu çalışmada üç farklı çalışma grubunda yeralan toplam 545 öğrenci ile çalışılmıştır. Açımlayıcı faktör analizi için çalışılan ilk grubu farklı üniversiteden toplam 291 kişi oluşturmaktadır. Katılımciların 219'u (\% 75,8) kadın, 80’i (\% 24,2) erkek iken 2 kissi cinsiyetini yazmamıştır. Yaş açısından bakıldı̆̆ında katılımcılardan 192 kişinin 17-22 yaş aralığında (\% 66), 92 kişinin (\% 31,6) 23-28 yaş aralığında ve 7 kişinin (\% 2,4) 29 yaş ve üstü olduğu belirlenmiştir. Çalışmanın ikinci grubunu 156 kişi oluşturmaktadır. Katılımcıların 103’ü (\% 66,1) kadın, 53’ü (\% 33,9) erkektir. Yaş açısından bakıldığında katılımcılardan 120 kişinin 17-22 yaş aralığında (\% 77), 25 kişinin (\% 16) 2328 yaş aralığında ve 11 kişinin (\% 7) 29 yaş ve üstü olduğu belirlenmiştir. Çalışmanın üçüncü grubunu 98 kişi oluşturmaktadır. Katılımcıların 85'i kadın (\% 86.73), 13’ü (\% 13.27) erkektir. Sınıf açısından bakıldığında katılımcıların 29'u üçüncü sınıf, 68'i son sınıf öğrencisidir ve bir katılımc1 sınıfını yazmamıştır. Bu grubun verileri benzer ölçekler geçerliği ve iç tutarlılık katsayının yeniden hesaplanması amacıyla kullanılmıştır.

\subsection{Madde yazım süreci}

Her bir boyut için madde hazırlıkları, ilgili alan yazındaki kuramsal açıklamalar (Örneğin, Corbin, Welk, Corbin ve Welk, 2006; Hettler, 1980, Miller ve Foster, 2010; Myers, Sweeney ve Witmer, 2000), ilgili ölçeklerdeki (Örneğin, Adams, Bezner ve Steinhardt, 1997; Güneri, 2003; Myers ve Sweeney, 2004) maddeler incelendikten sonra araştırmacılar tarafindan yeni maddeler yazılarak gerçekleştirilmiştir. İlk etapta hazırlanan 103 madde önce araştırmacılar arasında yeniden tartısılarak azaltılmıştır. Ardından madde havuzu dört psikolojik danışma alanındaki akademisyenlere iletilerek maddelerin anlaşılır olup olmamasına ve hangi boyutlara gidebileceğine ilişskin geri bildirim alınmışır. Gelen geri bildirimlere göre, bazı maddelerin ifadeleri yeniden gözden geçirilerek ölçeğin 59 maddelik ve beşli derecelemeli taslak hali elde edilmiştir.

\subsection{Benzer ölçekler geçerliği çalışması}

Benzer ölçekler geçerliği için Bahar, Beşer, Gördes, Ersin ve Kıssal (2008), tarafindan Türkçe'ye uyarlanan Sağlıklı Yaşam Biçimi Davranışları Ölçeği-II kullanılmıştır. Bu amaçla önce ölçeği uyarlayanlarla bağlantı kurularak kullanma için izin istenmiştir. Sağlıklı Yaşam Biçimi Davranışları Ölçeği II önce Walker, Sechrist ve Pender (1987) tarafindan geliştirilmiş, ardından yılında 1996 yeniden gözden geçirilmiştir (Walker ve Hill-Polerecky, 1996). Ölçek bireyin sağllklı yaşam biçimi ile ilişkili olarak sağlığı geliştiren davranışlan ölçmektedir. Ölçek toplam 52 maddeden oluşmuş olup altı alt faktörü vardır. Alt gruplar, manevi gelişim, sağllk sorumluluğu, fiziksel aktivite, beslenme, kişilerarası ilişkiler ve stres yönetimidir. Ölçeğin genel puanı sağlıklı yaşam biçimi davranışları puanını vermektedir. Ölçeğin tüm maddeleri olumludur. Derecelendirme 4’lü likert şeklindedir. Hiçbir zaman (1), bazen (2), sık sık (3), düzenli olarak (4) olarak kabul edilmektedir. Ölçeğin tamamı için en düşük puan 52, en yüksek puan 208'dir. Ölçeğin Alpha güvenirlik katsayıs1 0.94'dir. Ölçeğin alt faktörlerinin Alpha iç tutarlılık katsayıları 0.79-0.87 arasında değişmektedir (Bahar, Beşer, Gördes, Ersin ve Kıssal, 2008). Bu çalışma için 98 kişi üzerinden hesaplanan iç tutarlık katsayısı 0.93 olarak elde edilmiştir

\subsection{Veri toplama süreci}

Araştırmanın verileri iki farklı yolla toplanmıştır. İlk iki grubun verileri online veri toplama yolu olan Kwiksurvey sisteminden yararlanılarak toplanmıştır. Son grubun verileri ise araştırmacılardan birisi tarafindan kağıt kalem testi biçiminde uygulama yapılarak toplanmıştır. 
Korkut Owen, F., Doğan, T., Demirbaş Çelik, N., \& Owen, D. W. (2016). İyilik Hali Yıldızı Ölçeği’nin geliştirilmesi. Journal of Human Sciences, 13(3), 5013-5031. doi:10.14687/jhs.v13i3.4130

\subsection{Verilen analizi}

İHYÖ'nin geçerliliğini test etmek için SPSS 20 programı ve LISREL 8.80 programı kullanılmışır. Öncelikle SPSS programında faktör analizi ve güvenirlik katsayısı hesaplanmıştır. Faktör analizi için Kaise-Meyer-Olkin (KMO) ve Bartlett küresellik değerleri hesaplanmıştır. Faktör analizine dahil edilecek faktör sayısını belirlenmesinde temel ölçüt olarak Eigen değeri 1.00 üzerinde olan maddeler alınmıştır (Büyüköztürk, 2010). İHYÖ'nin güvenirliği, Cronbach's Alfa katsayısı, düzeltilmiş madde toplam korelasyon katsayısı ile belirlenmiştir. İHYÖ’nin faktör yapısının ve güvenirliğinin belirlenmesinin ardından LISREL programında doğrulayıcı faktör analizi (DFA) yapılmıştır. DFA sonucunda elde edilen modelin değerleri uyum iyiliği istatistikleri ile değerlendirilmiştir. En yaygın olarak kullanılan uyum iyiliği istatistiklerinin Serbestlik Derecesi ( $\chi 2)$, GFI, CFI, SRMR ve RMSEA değerleridir (Şimşek, 2007, s.14). Bu uyum istatistiklerinin ölçütleri Çelik ve Yılmaz (2013, s. 39) tarafindan şöyle özetlenmiştir: Bu ölçütlerden $\chi 2$ 'nin 2'nin altında olması iyi uyumu, 3'ün altında olması kabul edilebilir uyumu belirtmektedir. IFI ve CFI'nın 0.95'in, üzerinde olması iyi uyumu, 0.90'ın üzerinde olması kabul edilebilir uyumu göstermektedir. SRMR ve RMSEA'nin 0.05'un altında olması iyi uyumu; SRMR'nin 0.10'un, RMSEA'nın 0.08'in altında olması kabul edilebilir uyumu işaret etmektedir.

\section{Bulgular}

\subsection{Madde analizi}

İlk faktör analizine toplam 59 madde ile başlanmıştır. İlk analizde döndürme işlemi yapılmış ve ölçeğin sekiz alt boyuttan oluştuğu görülmüştür. Bu ilk analizde; 3, 18, 27, 32, ve 58. maddeler birden fazla boyutta yer aldığ1 ve extraction değerleri .30'un altında olduğu için ölçekten çıkarılmıştır. Bu işlemin ardından Varimax Dik Döndürme Tekniği Kullanılarak 54 madde ile faktör analizi yeniden yapılmıştır. Bu analiz sonucunda yedi boyutlu bir yapı elde edilmiştir. $\mathrm{Bu}$ analizden sonra 4. ve 34. maddeler ayrı bir boyut oluşturduğu için ölçekten çıkarılmıştır. Birden fazla boyuta yüklenen ve extraction değerleri .30'un altında olan 1, 7, 9, 13, 23, 24, 27, 28, 31 ve 55 maddelerin maddelerin anlamsal yapıları incelenerek ölçekten çıkarılmasına karar verilmiştir. Üçüncü faktör analizi 41 madde üzerinden gerçekleştirilmiştir. Üçüncü analizde15, 33, 37, 40, 46 ve 52. Maddeler; dördüncü faktör analizinde ise 4, 5, 41, 44, 49 ve 51. maddeler yukarıda sözü edilen gerekçelerle çıkarılmıştur. Kalan 34 madde tekrar faktör analizine tabi tutulmuştur. Beşinci faktör analizi sonucunda altı faktörlü yapı oluşmuştur. Ancak bir faktörde yalnızca 14 ve 30 . maddeler yer aldığı için bu iki madde ölçeğe dahil edilmemiştir. Bu 32 madde için son alt \%27 ve üst \%27'lik grupların madde ortalama puanları arasındaki farkların ilişkisiz grup t testi kullanılarak yapılan ayırt edicilik analizlerinde 11,20 ve 35 ve 39. maddelerin ortalamalarının istatistiksel ayırdedici olamadıkları görülmüsstür. Bu nedenle faktör analizine dahil edilmemişlerdir. Kalan 28 madde üzerinden yapılan faktör analizi sonucunda birden fazla boyuta yüklenen ve anlamsal olarak farklı boyutu işaret eden 10, 25, 26 ve 59. maddeler ölçekten çıkarılmıştır. Sonuç olarak 24 maddeden oluşan 5 boyutlu bir yapı oluşmuştur. Tablo 1'de ölçeğinin maddelerine ilişkin tanımlayıcı istatistikler verilmiştir. Faktör yapısına ilişkin scree plot grafiği ise Şekil 1'de yer almaktadir. 
Korkut Owen, F., Doğan, T., Demirbaş Çelik, N., \& Owen, D. W. (2016). İyilik Hali Yıldızı Ölçeği’nin geliştirilmesi. Journal of Human Sciences, 13(3), 5013-5031. doi:10.14687/jhs.v13i3.4130

Tablo 1: IHHYÖ'nin Maddelerine İlişkin Tanımlayıcı İstatistikler

\begin{tabular}{lccc}
\hline & $\bar{X}$ & SS & Madde Toplam Korelasyonlar1 \\
\hline M1 & 4.33 & .789 & .518 \\
M2 & 4.52 & .645 & .400 \\
M3 & 3.71 & .951 & .296 \\
M4 & 3.10 & 1.081 & .329 \\
M5 & 4.36 & .751 & .563 \\
M6 & 3.85 & .912 & .563 \\
M7 & 4.34 & .679 & .464 \\
M8 & 4.27 & .846 & .230 \\
M9 & 2.24 & 1.065 & .292 \\
M10 & 4.39 & .641 & .439 \\
M11 & 4.14 & .848 & .427 \\
M12 & 4.53 & .639 & .425 \\
M13 & 3.61 & 1.039 & .401 \\
M14 & 2.91 & 1.286 & .278 \\
M15 & 4.44 & .742 & .422 \\
M16 & 4.07 & .783 & .613 \\
M17 & 4.30 & .708 & .494 \\
M18 & 3.49 & 1.296 & .494 \\
M19 & 4.14 & .782 & .184 \\
M20 & 3.94 & .801 & .201 \\
M21 & 4.06 & .707 & .464 \\
M22 & 4.04 & .868 & .456 \\
M23 & 4.33 & .739 & .635 \\
M24 & 4.52 & .789 & .626 \\
\hline
\end{tabular}




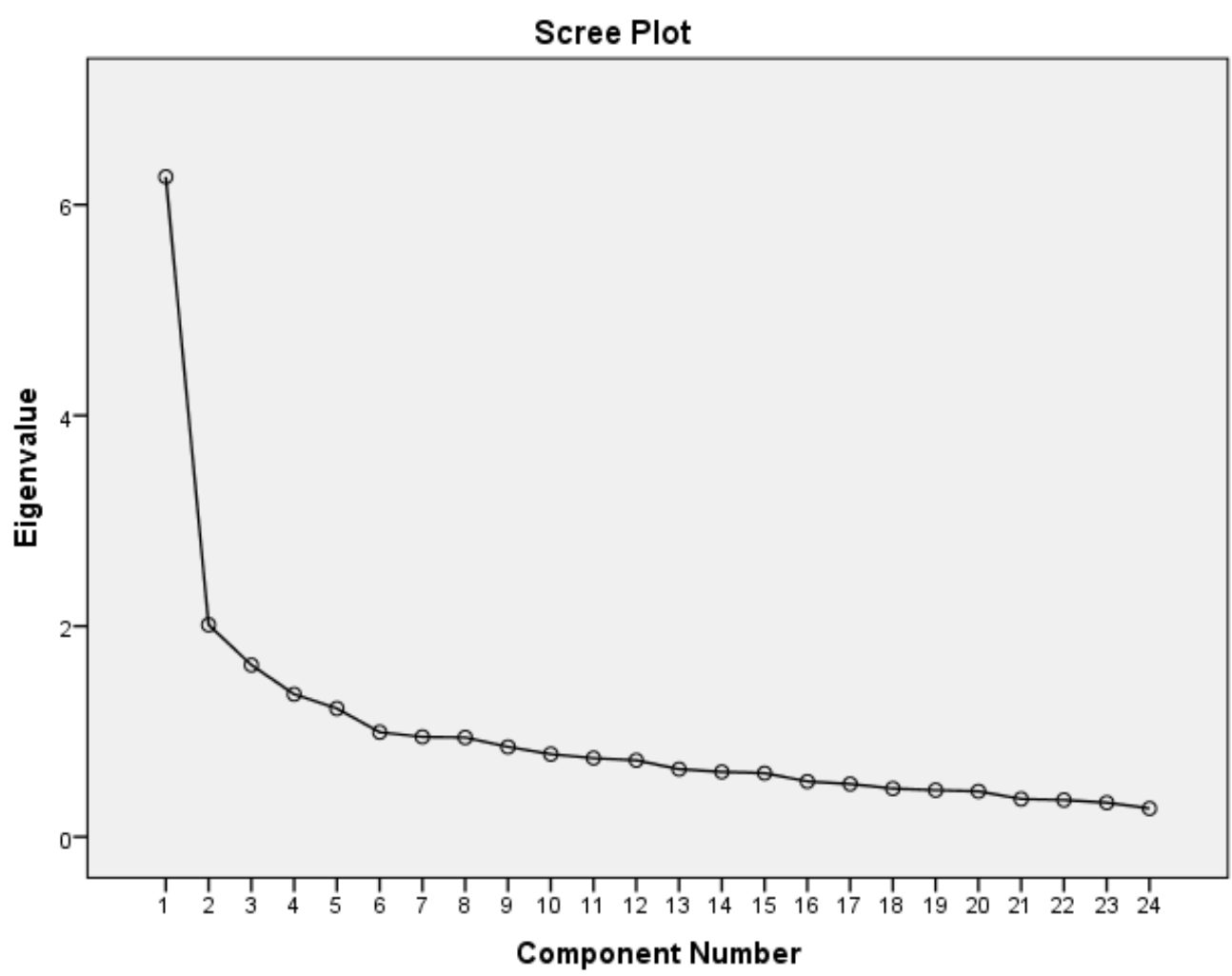

Şekil 1. İHYÖ'nun Faktör Yapısına Ilişkin Scree Plot Grafiği

\subsection{Açıklayıcı faktör analizi (AFA) sonuçları}

Ölçeğin yap1 geçerliğini test etmek amacıyla Temel Bileşenler Analizi varimax döndürme yöntemi kullanılarak yapılmıştır. Faktör analizi için KMO (0.84) ve Bartlett küresellik $(\chi 2=2058)$ değerlerinin yeterli olduğu bulunmuştur. Bu analiz sonucunda 0.40 ile 0.76 arasında yük değerleri alan beş faktörlü bir yap1 ortaya çıkmıştır. Bu yap1, toplam varyansın \% 51.9’unu açıklamaktadır. Birinci faktör toplam varyansın \% 26.1'ini ikinci faktör toplam varyansın \% 8.3'ünü, üçüncü faktör toplam varyansin \% 6.7'sini, dördüncü faktör toplam varyansin \% 5.6'sını ve beşinci faktör toplam varyansın \% 5'ni açıklamaktadır. Yedi maddeden $(1,6,11,16,21,23,24)$ oluşan birinci faktör 'yaşam anlamlandirma ve hedef odakh olma' olarak isimlendirilmiştir. İkinci boyut $(2,7,12,17)$ dört maddeden oluşmaktadır ve 'bilişsel boyut' olarak ele alınmıştır. Beş maddeden $(3,8,13,18,22)$ oluşan üçüncü boyut, 'duygusal boyut' olarak ele alınmıştr. Dördüncü boyut $(4,9,14,19)$ ve beşinci boyut $(5,10,15,20)$ dörder maddeden oluşmaktadır ve sirasıyla 'firitksel' ve 'sosyal' olarak isimlendirilmiştir. Her bir maddenin faktör yükleri ve girdikleri boyutlar Tablo 2'de sunulmuştur. 
Korkut Owen, F., Doğan, T., Demirbaş Çelik, N., \& Owen, D. W. (2016). İyilik Hali Yıldızı Ölçeği’nin geliştirilmesi. Journal of Human Sciences, 13(3), 5013-5031. doi:10.14687/jhs.v13i3.4130

Tablo 2. AFA Sonucuna Göre IHHŸO’ne Ait Maddelerin Faktör Yükleri

\begin{tabular}{|c|c|c|c|c|c|}
\hline & I. Faktör & $\begin{array}{c}\text { II. } \\
\text { Faktör }\end{array}$ & $\begin{array}{c}\text { III. } \\
\text { Faktör }\end{array}$ & $\begin{array}{c}\text { IV. } \\
\text { Faktör }\end{array}$ & $\begin{array}{c}\mathrm{V} . \\
\text { Faktör }\end{array}$ \\
\hline M16 & .768 & & & & \\
\hline M11 & .713 & & & & \\
\hline M6 & .671 & & & & \\
\hline M21 & .623 & & & & \\
\hline M1 & .620 & & & & \\
\hline M23 & .574 & & & & \\
\hline M24 & .522 & & & & \\
\hline M12 & & .765 & & & \\
\hline M7 & & .728 & & & \\
\hline M17 & & .716 & & & \\
\hline M2 & & .703 & & & \\
\hline M13 & & & .637 & & \\
\hline M8 & & & .612 & & \\
\hline M3 & & & .512 & & \\
\hline M18 & & & .489 & & \\
\hline M22 & & & .405 & & \\
\hline M4 & & & & .716 & \\
\hline M9 & & & & .680 & \\
\hline M14 & & & & .651 & \\
\hline M19 & & & & .462 & \\
\hline M20 & & & & & .716 \\
\hline M15 & & & & & .660 \\
\hline M5 & & & & & .617 \\
\hline M10 & & & & & .520 \\
\hline
\end{tabular}

\subsection{Doğrulayıcı faktör analizi sonuçlanı}

İHYÖ'nin beş faktörlü yapısı üzerinde veriyi en iyi olasılıkla tahmin etme yöntemiyle DFA yapılmıştur. DFA sonucu elde edilen uyum iyiliği istatistikleri elde edilen yapının kabul edilebilir olduğunu göstermektedir: $[\chi 2(239, \mathrm{~N}=156)=490.28, \mathrm{p}<0.01 ; \mathrm{CFI}=0.90$; IFI $=0.90 ;$ SRMR $=0.085$; RMSEA $=0.082]$ şeklindedir. Elde edilen DFA sonucu faktör yükleri, $\mathrm{t}$ değerleri ve standart hata değerleri Tablo 3’te sunulmuştur. Buna göre faktörler 0.47 ile 0.91 arasında değerler almaktadırlar. 
Korkut Owen, F., Doğan, T., Demirbaş Çelik, N., \& Owen, D. W. (2016). İyilik Hali Yıldızı Ölçeği’nin geliştirilmesi. Journal of Human Sciences, 13(3), 5013-5031. doi:10.14687/jhs.v13i3.4130

Tablo 3. DFA Sonucuna Göre IHHYÖ'ne Ait Maddelerin Faktör Yükleri, Standart Hata ve t Değerleri

\begin{tabular}{lccc}
\hline & Faktör Yükleri & Standart Hata & $\mathrm{t}$ \\
\hline M1 & 0.54 & 0.71 & 6.85 \\
M2 & 0.62 & 0.61 & 8.09 \\
M3 & 0.48 & 0.77 & 5.58 \\
M4 & 0.66 & 0.56 & 7.64 \\
M5 & 0.69 & 0.52 & 8.82 \\
M6 & 0.61 & 0.62 & 8.01 \\
M7 & 0.91 & 0.18 & 13.54 \\
M8 & 0.47 & 0.78 & 5.48 \\
M9 & 0.55 & 0.70 & 6.22 \\
M10 & 0.62 & 7.72 \\
M11 & 0.43 & 10.52 \\
M12 & 0.62 & 0.44 & 10.36 \\
M13 & 0.75 & 0.65 & 7.17 \\
M14 & 0.75 & 0.78 & 5.21 \\
M15 & 0.59 & 0.38 & 10.42 \\
M16 & 0.47 & 0.36 & 11.48 \\
M17 & 0.69 & 9.92 \\
M18 & 0.79 & 0.48 & 6.78 \\
M19 & 0.80 & 0.63 & 7.00 \\
M20 & 0.72 & 0.67 & 7.04 \\
M21 & 0.57 & 0.53 & 9.27 \\
M22 & 0.61 & 6.64 \\
M23 & 0.63 & 8.11 \\
M24 & 0.57 & & 7.86 \\
\hline
\end{tabular}

\subsection{Benzer ölçekler geçerlik sonuçları}

Bahar ve arkadaşları (2008) tarafindan Türkçe'ye uyarlanan Sağlıklı Yaşam Biçimi Davranışları Ölçeği-II ile İHYÖ arasında hesaplanan korelasyon katsayısı $r=0.765,(p<.0001)$ olarak elde edilmiştir. Bu durumda iki ölçek arasında güçlü sayılabilecek bir ilişki bulunmaktadır. Elde edilen bu değer benzer ölçekler geçerliği için oldukça iyi bir değer olarak düşünülmüştür.

\section{5. Ölçeğin güvenirliğine ilişkin bulgular}

Açıklayıcı faktör analizi çalışmalarında yeralan 291 kişiden elde edilen veriler göre yapılan iç tutarlılık katsayısı hesaplamasında ölçeğin toplamı için $\mathrm{r}=0.84(\mathrm{p}<.01)$, yaşamı anlamlandırma ve hedef odaklı olma, bilişsel, duygusal, fiziksel ve sosyal alt boyutları için sırasıyla $0.83 ; 0.72,0.60$, 0.57 ve 0.65 olarak hesaplanmıştır. Araştırmanın üçüncü grubundaki 98 kişiden oluşan gruptan elde edilen verilere göre ölçeğin toplamı için iç tutarlılık katsayısı $\mathrm{r}=0.85(\mathrm{p}<.01)$ olarak elde edilmiştir. Alt boyutlardan elde edilen katsayılar ise sirasılyla $0.79 ; 0.77 ; 0.63 ; 0.57$ ve 0.71 olarak bulunmuştur. 
Korkut Owen, F., Doğan, T., Demirbaş Çelik, N., \& Owen, D. W. (2016). İyilik Hali Yıldızı Ölçeği’nin geliştirilmesi. Journal of Human Sciences, 13(3), 5013-5031. doi:10.14687/jhs.v13i3.4130

\section{Tartışma ve yorum}

Bu çalışmada İyilik Hali Yıldızı Modeli’ne dayalı olarak bir ölçek geliştirilmeye çalışılmıştır. Ölçek geliştirme sürecinde gerçekleştirilen analizlere ilişkin tartısma ve yorumlar aşağıda verilmiştir. Ölçeğin bazı maddelerin, madde analizleri aşamasında birkaç boyuta dağıldıkları ya da faktör değerlerinin beklenenden düşük olduğu görülmüsstür. $\mathrm{Bu}$ nedenle o maddelerin analizlerden çıkarılması işlemlerinin beş aşamada yapılması gerekmiştir. Ölçeğin maddeleri böylece 59 maddeden 24 maddeye düşmüştür. Maddelerin bu kadar düşmesinin nedenlerinden birisi hazırlanan bazı maddelerin iyilik halinin birkaç boyutuna da gidecek biçimde olmasıyla açıklanabilir. Genel iyilik hali alt boyutlardan oluşsa da boyutların birbirleriyle etkileşimde olduğu bütüncül bir yap1 göstermektedir (Miller ve Foster, 2010; Myers ve Sweeney, 2004). Bu durumda alt yapıları net olarak ayırd etmek zor olmaktadır. Ölçeğin yap1 geçerliği için yapılan analizlerde ölçeğin, maddeleri 0.40 ile 0.76 arasında yük değerleri alan beş faktörlü bir yapısı olduğu ortaya çıkmıştır. Bu yapı, toplam varyansın \% 52'lik bir kısmını açıklamaktadır. Bu değerin daha yüksek olması beklense de elde edilen değer de kabul edilebilir derecededir (Beavers, Lounsbury, Richards, Huck, Skolits ve Esquivel, 2013). Doğrulayıcı faktör analizi sonuçlarına göre elde edilen değerler elde edilen bu yapıyı desteklemektedir. DFA sonucu elde edilen uyum iyiliği istatistikleri Çelik ve Yılmaz (2013) tarafından belirtilen ölçütlerle karşılaştırıldığında elde edilen yapının kabul edilebilir olduğunu göstermektedir. Benzer ölçekler geçerliğinde kullanılan Sağlıklı Yaşam Biçimi Davranışları Ölçeği II yurt içi ve dışında çok sayıda araştırmada (Örn., İlhan, Bahadırlı ve ErcanToptaner, 2014; Lee ve Yuen- Lok, 2005; Tambağ, 2011; Yüksel, 2012) kullanılmıştur. SYBDÖ ile İHYO ile arasında oldukça yüksek bir korelasyon saptanması geliştirilen ölçeğin geçerliği için önemli bir gösterge olarak ele alınmaktadır.

Güvenirlik çalışması için iki ayrı gruptan elde edilen verilere göre hesaplanan toplam puana ilişkin iç tutarlllık kat sayıları 0.83 ve 0.85 'dir. Büyüköztürk (2010 s. 171) tarafindan 0.70-1.00 arasındaki değerler yüksek olarak değerlendirilmektedir. İki gruptan elde edilen verilere göre alt boyutlara ilişkin iç tutarlılık kat sayıları da ilk grupta 0.60 ile 0.83, ikinci grupta ise 0.57-0.79 arasında değişmektedir. Değerlere bakıldığında bazılarının yüksek bazıların ise Büyüköztürk'e (2010) göre 0.69 ile 0.30 arasında olduğu için orta derecede olduğunu görülmektedir. Madde toplam korelasyonunun yorumlanmasında 0.30 ve daha yüksek olan maddelerin bireyleri ölçülen özellik bakımından iyi derecede ayırt ettiği işaret edilmektedir (Büyüköztürk, 2010). Buna göre M8, M14, M19 ve M20'nin dişındaki 20 maddenin yükleri göz önüne alındığında 0.30'un üzerindedir ve ayırt edicilikleri oldukça yüksektir. M8, M14 ve M20'nin yükleri ise.20-.30 arasında değer almaktadır bu da Büyüköztürk'e göre (2010) maddelerin zorunlu görülmesi durumunda ölçeğe alınabileceğinin kanıtıdır. M19'un ise ayırt ediciliği 0.18 'dir ancak madde yükü daha yükü ve DFA sonucu dikkate alınarak ölçeğe dahil edilmiştir. Sonuç olarak söz konusu değerlerin ölçeğin güvenirliği için oldukça iyi değerler olduğu söylenebilir.

Ölçeğin alt boyutlarının adlandırılması Korkut Owen ve Owen (2012) tarafindan geliştirilen İyilik Hali Yıldızı Modelinde sunulan adlar dikkate alınsa da bazı boyutlann adlarında bazı değişiklikler yapılmıştır. Fiziksel ve sosyal boyut adları aynen korunurken üç boyutta isimlendirme konusunda değişiklik yapılmıştır. Entelektüel / mesleki iyilik hali boyutuna ilişkin yazılan maddelerde mesleki kısımla ilgili olan maddeler işlemeyince o boyuta önce sadece entelektüel iyilik hali denmesi düşünülmüş ardından bilişsel boyut adı verilmesinin daha uygun olacağına karar verilmiştir. Psikolojik / duygusal iyilik hali boyutuna sadeleştirme adına duygusal iyilik hali denmiştir. Ad değişikliğine gidilen spiritüel boyuta, daha kolay anlaşılabilir bir Türkçe olması açısından yaşamı anlamlandırma ve hedef odaklı olma denmesi kararlaştırılmışıtır. 
Korkut Owen, F., Doğan, T., Demirbaş Çelik, N., \& Owen, D. W. (2016). İyilik Hali Yıldızı Ölçeği’nin geliştirilmesi. Journal of Human Sciences, 13(3), 5013-5031. doi:10.14687/ihs.v13i3.4130

\section{Sonuç ve öneriler}

Son yıllarda, üniversite psikolojik danışma merkezlerine başvuru düzeyinin artığı, öğrencilerin problemlerinin ve ihtiyaçlarının çeşitlendiği (Holm-Hadullaa ve Koutsoukou-Argyrakia, 2015; Kitzrow, 2003) görülmektedir. Yaşam boyu karşllaşılan ruhsal bozuklukların dörde üçü 24 yaşına kadar olan sürede olmaktadır (Kessler Berglund, Demler, Jin, Merikangas ve Walters, 2005; s. 593), dolayısıyla tipik üniversite yıllarına rastlayan 18-24 yaş aralığının, ömür boyu süren bazı ruhsal bozukluklarının başlangıcı olarak ifade edilebilir. Bilindiği üzere, kronik hastalıklar tedavisi zor ve pahalı bir süreçtir ve ülke ekonomisine ağır bir yük getirebilmektedir. Bu nedenle bu hastalıkların kronikleşmesini engelleyecek ve sağlı̆ğ ve dolayısıyla iyilik halini güçlendirici önleyici çalışmaların yapılması birçok açıdan önemli katkılar sağlayacaktır. Diğer bir deyişle, insanların daha sağlıklı bir yaşam tarzını ve dolayısıyla daha iyi bir iyilik haline sahip olmaları için bilinçlendirilmeleri gereklidir. Nitekim yapılan çalışmaların sonuçları iyilik hali programlarının etkinliğini göstermektedir (Burkett, Rena, Stone ve Klein 2002; Parks ve Steelman, 2008; Williams, Kolar, Reger ve Pearson, 2001). Üniversite öğrencileri akademik ve kişisel yaşamlanının getirdiği talepleri gerçekleştirmeye çalışırken kendi iyilik hallerini gözardı edebilmektedirler. Bu durumda, iyilik halinin belirlenmesi, sonuçlarına göre gerekli önlemlerin alınması ve öğretim ortamlarında gerekli düzenlemelerin yapılması gerekmektedir. Gerekli önlemlerin alınması ve eğitim ortamında gerekli düzenlemelerin yapılabilmesi için öncelikle mevcut durumun saptanması gereklidir. Daha açık bir ifade ile üniversite öğrencilerinin sağlık ve iyilik halini geliştirmek için öncelikle onların iyilik hallerinin saptanmasını gerekli kılmaktadır. Bu ihtiyaç göz önünde bulundurarak, bu çalışma ile, Türkiye’ye özgü bir iyilik hali modelini, diğer bir deyişle, İyilik Hali Yıldızı Modeli’ni temel alarak üniversite öğrencilerine ve yetişkinlere yönelik yeni bir ölçek geliştirilmiştir. Geliştirilen bu ölçme aracının, bireylerin iyilik halinin değerlendirilmesine yönelik alanyazının gelişmesine önemli bir katkı sağlayacağı düşünülmektedir.

İyilik Hali Yıldız Modeline dayalı olarak geliştirilmeye çalışılan ölçeğin psikometrik çalışma sonuçları ölçeğin genç yetişkin olan üniversite öğrencileri için güvenilir ve geçerli olduğunu göstermektedir. $\mathrm{Bu}$ durumda üniversitelerin psikolojik danışma merkezleri aracilı̆̆ ile tüm öğrencilere ve çalışanlara yönelik iyilik haliyle ilgili tarama çalışmalarında ölçekten yararlanılabileceği düşünülmektedir. Üniversite yıllarının gençler için bir dizi geçişlerin yaşandığ1 zorlu yıllar olması nedeniyle onların iyilik hallerini anlamaya ve artırmaya yönelik yapılacak bireysel ve grup çalışmalarında bu ölçek yardımcı olabilir. Ölçek ayrıca İyilik Hali Yıldızı Modeline ya da farklı modellere dayalı olarak geliştirilen iyilik halini artırmaya yönelik programlann etkililiklerini sınamak için de kullanılabilir. Geç ergenlik ve yetişkinliğin ilk yılları birçok yaşam tarzı kararının alındığı bir zaman dilimi olması nedeniyle, üniversitede sağlığı artınıcı ortamların ve etkinliklerin düzenlenmesi çok önemlidir ve üniversitelerde özellikle, başta Psikolojik Danışma ve Rehberlik Merkezleri olmak üzere bütün üniversite çalışanlarına bu konuda önemli görevler düşmektedir. $\mathrm{Bu}$ çalışmaların etkililiği kurumdaki bütün görevlilerin işbirliği yapmasıyla gerçekleştirilebilir. $\mathrm{Bu}$ noktada aslında iyilik hali programlarının sadece eğitim kurumlarında değil, birçok farklı kurumda uygulanabileceğinin de belirtilmesi gerekir.

Ölçeğin geliştirilmesi üniversite öğrencileri ile gerçekleştirildiği için gelecekte farklı yaş ve eğitim düzeylerindeki örneklem gruplarıyla sınanabilir. Özellikle çocukluk ve ergenlik yıllarının sağlıklı ve sağlıklı olmayan yaşam biçimiyle ilgili alışkanlıkların edinildiği yıllar olarak vurgulanması (Santrock, 2007), ergenlerin iyilik halinin gelecekteki sağlı̆ıın ve yaşam stili alışkanlıklarının önemli bir göstergesi olması nedeniyle o döneme yönelik çalışmalara ağırlık verilebilir. Çocuklukta kazanılan sağlıklı tutumların ileriki yaşların da sağlıklı geçirilmesine önemli katkılar sağlar. Ölçeğin, psikolojik sağlamlık, kendine güven, denetim odağı, risk alma davranışı gibi diğer psikolojik yapılarla ilşkisine yönelik çalışmalar da yapılabilir. Son olarak, iyilik halinin boyutlarının açıklanmasına yönelik nicel araştırmaların yanısıra nitel araştırmalar da yapılabilir. 
Korkut Owen, F., Doğan, T., Demirbaş Çelik, N., \& Owen, D. W. (2016). İyilik Hali Yıldızı Ölçeği’nin geliştirilmesi. Journal of Human Sciences, 13(3), 5013-5031. doi:10.14687/jhs.v13i3.4130

\section{Kaynaklar}

Adams, T., Bezner, J. ve Steinhardt, M., (1997). The conceptualization and measurement of perceived wellness: Integrating balance across and within dimensions. American Journal of Health Promotion, 11(3), 208-218.

American Counseling Association (2010). 20/20: Consensus definition of counseling, http://www.counseling.org/knowledge-center/20-20-a-vision-for-the-future-ofcounseling/consensus-definition-of-counseling.

Ardell, D.B. (1977). High level wellness: An alternative to doctors, drugs, and disease, Emmaus, PA: Rodale Press.

Beavers, A. S., Lounsbury, J. W., Richards, J. K., Huck, S. W., Skolits, G. J. \& Esquivel, S. L. (2013). Practical considerations for using exploratory factor analysis in educational research. Practical Assessment, Research and Evaluation, 18(6). Available online: http://pareonline.net/getvn.asp?v $=18 \& n=6$

Bedir, S. ve Kocabaş, F. (2015). Rejeneratif biyoloji. 12 Temmuz 2016 tarihinde http://www.acikbilim.com/2015/07/dosyalar/rejeneratif-biyoloji.html adresinden erișilmiștir.

Burkett, L.N., Rena, C.G., Stone, K.W.J. ve Klein, D.A. (2002). The effect of wellness education on the body image of college students. Health Promotion Practice, 3(1), 76-82.

Büyüköztürk, Ş. (2010). Sosyal bilimler için veri analiæ̨i el kitabı (12.Bask1). Ankara: PegemA Akademi Yayınevi

Corbin, C. B., Welk, G. J., Corbin, W. R. ve Welk, K. (2006). Concepts of fitness and wellness (5th ed.). St. Louis: McGraw-Hill Higher Education.

Cowen, E.L. ve Durlak, J.A. (2000). Social policy and prevention in mental health. Development and Psychopathology, 12(4), 815-834.

Çelik, H. E. ve Yılmaz, V. (2013). Lisrel 9.1 ile yapısal eșitlik modellemesi: Temel kavramlar - uygulamalar programlama (2.baskı). Ankara: Anı Yayıncilik.

Depken, D. (1994). Wellness through the lens a gender: A paradigm shift. Wellness Perspectives, 10(2), 54-71.

Diener, E., Wirtz, D., Tov, W., Kim-Priet, C., Choi, D., Oishi, S. ve Biswas-Diener, R. (2010) New well-being measures: Short scales to assess flourishing and positive and negative feelings, Social Indicator Reseserach, 97, 143-156. DOI 10.1007/s11205-009-9493-y

Dixon-Rayle, A.D. ve Myers, J.E. (2004). Counseling adolescents toward wellness: The roles of ethnic identity, acculturation, and mattering. Professional School Counseling, 8(1), 81-90.

Doğan, T. (2004). Üniversite ögrencilerinin iyilike halinin incelenmesi, Hacettepe Üniversitesi, Ankara, yayınlanmamış doktora tezi.

Doğan, T. (2006a). Üniversite öğrencilerinin iyilik halinin incelenmesi. Hacettepe Üniversitesi Eğgitim Fakültesi Dergisi, 30, 120-129.

Doğan, T. (2006b). Üniversite öğrencilerinin iyilik halinin "maneviyat" ve "serbest zaman" boyutlanının incelenmesi. Türk Psikolojik Damısma ve Rehberlik Dergisi, 3(26), 1-16.

Doğan, T. (2008). Psikolojik belirtilerin yordayıcısı olarak sosyal destek ve iyilik hali. Türk Psikolojik Danısma ve Rebberlike Dergisi, 3(30), 30-44.

Doğan, T., Yıldırım, İ. (2006). Üniversite öğrencilerinin iyilik halinin "arkadaşlık" ve "sevgi” boyutlarının incelenmesi. Eğitim Araștirmalar, 24, 77-86. 
Korkut Owen, F., Doğan, T., Demirbaş Çelik, N., \& Owen, D. W. (2016). İyilik Hali Yıldızı Ölçeği’nin geliştirilmesi. Journal of Human Sciences, 13(3), 5013-5031. doi:10.14687/jhs.v13i3.4130

Dunn, H.L. (1961). High-level wellness: A collection of twenty-nine short talks on different aspects of the theme "High-level wellness for man and society." Arlington, VA: Beatty Co

Fidan, M. ve Usta, F. (2013). İyilik hali ölçeğinin Türkçe formunun güvenirlik ve geçerliğinin incelenmesi, Ë̆itim ve Ögretim Araştrmalar Dergisi, 2(3), 265-269.

Gültekin, B.K. ve E. İrgil (2001). Uludağ Üniversitesi Tip Fakültesi öğrencilerinin sosyal aktiviteleri ve sağlıkla ilgili tutum ve davranışlan, Uludă̆ Üniversitesi T⿰力 Fakültesi Dergisi, 27(1-2-3), 3337.

Güneri-Yerin, O. (2003). Wellness Inventory, Yayınlanmamış Araştırma Raporu.

Hartwig, H. ve Myers, J. E. (2003). A different approach: Applying a wellness paradigm to adolescent female delinquents and offenders, Journal of Mental Health Counseling, 25, 57-75.

Hermon, D.A. ve Davis, G.A. (2004). College student wellness: A comparison between traditionaland nontraditional-age students, Journal of College Counseling, 7(1), 32-39.

Hettler, B. (1980). Wellness promotion on a university campus. Family and Community Health, 3(1), 77-95.

Holm-Hadullaa, R. M.,ve Koutsoukou-Argyrakia, A. (2015). Mental health of students in a globalized world: Prevalence of complaints and disorders, methods and effectivity of counseling, structure of mental health services for students. Mental Health Prevention

http://dx.doi.org/10.1016/j.mhp.2015.04.003 2212-6570/\& 2015

İlhan, N., Bahadırlı, S. ve Ercan-Toptaner, N. (2014). Üniversite öğrencilerinin ruhsal durumları ile sağlık davranışlanı arasındaki ilişkinin belirlenmesi Marmara Üniversitesi Sağhlk Bilimleri Enstitïsü Dergisi, 4(4), 207-215.

İlhan, N., Batmaz, M. ve Utaş-Akhan (2010). Üniversite öğrencilerinin sağlıklı yaşam biçimi davranışları, Maltepe Üniversitesi Hemşirelik. Bilim ve Sanatı Dergisi, 3(3), 34-44

Jayanti, R K. ve Burns, A.C. (1998). The antecedents of preventive health care behavior: An empirical study. Journal of the Academy of Marketing Science, 26(1), 6-15. DOI: $10.1177 / 0092070398261002$.

Kasapoğlu, F. (2014). İyilik hali ile özgecilik arasındaki ilişkinin incelenmesi, Hikmet Yurdu, 7(13), 271 - 288.

Kessler, R. C., Berglund, P., Demler, O., Jin, R., Merikangas, K. R. ve Walters, E. E. (2005). Lifetime prevalence and age-of-onset distributions of DSM-IV disorders in the National Comorbidity Survey replication. Archives of General Psychiatry, 62, 593-602.

Kitzrow, M. A. (2003). The mental health needs of today's college students: Challenges and recommendations. NASPA Journal, 41,167-181.

Korkut-Owen, F. ve Öğretmen, T. (2013). Beş Faktörlü İyilik Hali Ölçeği-Ergen Formu: Türk ergenler. İnönü Üniversitesi Ë̆itim Fakültesi Dergisi, 14(1), 53-73.

Korkut-Owen, F. ve Owen. D.W. (2012). İyilik Hali Yıldız1 Modeli, uygulanması ve değerlendirilmesi. Uluslararası Avrasya Sosyal Bilimler Dergisi, 3(9), 24-33.

Laska, M. N., Pasch, K.E., Lust, K., Story, M. ve Ehlinger, E. (2009). Latent class analysis of lifestyle characteristics and health risk behaviors among college youth. Preventive Science, 10(4), 376-386. doi:10.1007/s11121-009-0140-2.

Lee, R.L.T. ve Yuen- Loke A.J.T. (2005). Health-promoting behaviors and psychosocial well-being of university students in Hong Kong, Public Health Nursing, 22(3), 209-220.

Memnun, S., (2006). Algzlanan esenlik ölçeğgnin geçerlik ve güvenirlik çalsşması ve beden eğitimi öğretmenlerinin esenlik algzlar. Yayımlanmamış Yüksek Lisans Tezi, Marmara Üniversitesi, Eğitim Bilimleri Enstitüsü, İstanbul. 
Korkut Owen, F., Doğan, T., Demirbaş Çelik, N., \& Owen, D. W. (2016). İyilik Hali Yıldızı Ölçeği’nin geliştirilmesi. Journal of Human Sciences, 13(3), 5013-5031. doi:10.14687/jhs.v13i3.4130

Miller, G.D. ve Foster, L.T. (2010). Critical synthesis of wellness literature. http://silvrnetwork.net/sites/silvrnetwork.org/files/library/Critical_Synthesis $\% 2520$ of $\% 2$ 520Wellness\%2520Update.pdf adresinden alınmıştır.

Myers, J. E. ve Sweeney, T. J. (2005). Counseling for wellness: Theory, research, and practice. Alexandria, VA: American Counseling Association.

Myers, J. E. ve Sweeney, T. J. (2004). The indivisible self: An evidence-based model of wellness. Journal of Individual Psychology, 60, 234-244.

Myers, J. E. (1992). Wellness, prevention, development: The cornerstone of the profession. Journal of Counseling and Development, 71, 136-139

Myers, J. E., Sweeney, T. J. ve Witmer, J. M. (2000). The wheel of wellness counseling for wellness: A holistic model for treatment planning. Journal of Counseling and Development, 78, 251-266.

Myers, J. E. ve Mobley, K. A. (2004). Wellness of undergraduates: Comparisons of traditional and nontraditional students. Journal of College Counseling 7, 40-49.

Oakland University William Beaumont School of Medicine (2015). Wellness at OUWB. http://www.oakland.edu/medicine/studentaffairs/wellness adresinden $26.12 \quad 2015$ tarihinde alınmıştır.

Oğuz-Duran, N. (2006). Wellness among Turkesh university students: Investigating the construct and testing the effectiveness of an art enriched wellness program. Yayınlanmamıs doktora tezi, Orta Doğu Teknik Üniversitesi, Sosyal Bilimler Enstitüsü, Ankara.

Oleckno, W. A. ve Blacconiere, M. J. (1990). Wellness of college students and differences by gender, race, and class standing. College Student Journal, 24(4), 421-429.

Parks, K.M. ve Steelman, L.A. (2008). Organizational wellness programs: A meta-analysis, Journal of Occupational Health Psychology, 13(1), 58 - 68.

Rachele, J. N., Washington, T. L., Cuddihy, T. F., Barwais, F. A. ve McPhail, S. M. (2013). Valid and reliable assessment of wellness among adolescents: Do you know what you're measuring? International Journal of Wellbeing, 3(2), 162-172. doi:10.5502/ijw.v3i2.3

Roothman, B., Kirsten, D. K. ve Wissing, M. (2003). Gender differences in aspects of psychological well being. South African Journal of Psychology, 33(4), 212-218.

Roscoe, L. J. (2009). Wellness: A review of theory and measurement for counselor. Journal of Counseling and Development. 87, 216-226.

Rotter, J.C. (2000). Happiness: Is it real or just an illusion? Family Journal Counseling and Therapy for Couples and Families, 8(4) 387-389.

Santrock, J.W. (2007). Essential life span development: New York: McGraw-Hill.

Sar1, T. (2003). Wellness and its' correlates among university students: Relationship status, gender, place of residence, and GPA, Unpublished master dissertation. Middle East Technical University, Ankara.

Schuster, T.L., Dobson, M., Jauregui, M. ve Blanks, R.H. (2004). Wellness lifestyles I: A theoretical framework linking wellness, health lifestyles, and complementary and alternative medicine, Journal of Alternative Complement Medicine, 10(2), 349-56.

Sidman, C.L., D’Abundo, M.L. ve Hritz, N. (2009). Exercise self-efficacy and perceived wellness among college students in a basic studies course, International Electronic Journal of Health Education, 12,162-174

Steiner, H., Pavelski, R., Pitts, T. ve McQuivey, R. (1998). The juvenile wellness and health survey (JWHS-76): A school based screening instrument for general and mental health in high school students. Child Psychiatry and Human Development, 29(2), 141-155. http://dx.doi.org/10.1023/A:1025088016749 
Korkut Owen, F., Doğan, T., Demirbaş Çelik, N., \& Owen, D. W. (2016). İyilik Hali Yıldızı Ölçeği’nin geliştirilmesi. Journal of Human Sciences, 13(3), 5013-5031. doi:10.14687/jhs.v13i3.4130

Sweeney, T. J. ve Witmer, J. M. (1991). Beyond social interest: Striving toward optimum health and wellness. Individual Psychology, 47, 527-540.

Şimşek, Ö. F. (2007). Yapısal eşitlik modellemesine giriş: Temel ilkeler ve LISREL uygulamalar. Ankara: Ekinoks Yayınları.

Tambağ, H. (2011). Hatay Sağlık Yüksekokulu öğrencilerinin sağlıklı yaşam biçimi davranışları ve etkileyen faktörler. Hacettepe Üniversitesi Sağhlk Bilimleri Fakültesi Hemşirelik Dergisi, 47-58.

Tripp, S. ve Stachowiak, B. (1992). Health maintanence, health promotion: Is there a difference? Public Health Nursing, 8(2),155-161.

Walker, S. N., Sechrist, K. R. ve Pender, N. J. (1987). The Health-Promoting Lifestyle Profile: Development and psychometric characteristics. Nursing Research, 36(2), 76-81.

Westgate, C. E. (1996). Spiritual wellness and depression. Journal of Counseling and Development, 75, 26-35.

Williams, K.A., Kolar, M.M., Reger, B.E. ve Pearson, J.C. (2001). Evaluation of a wellness-based mindfullness stress reduction intervention: A controlled trial. American Journal of Health Promotion, 15(6), 422-432.

World Health Organization (2003). WHO definition of health, http://www.who.int/about/definition/en/print.html.

Yarcheski, A., Mahon, N. E. ve Yarcheski, T. J. (2005). Psychometrics of the Laffrey Health Conception Scale for Adolescents. Journal of Nursing Measurement, 13(1), 65-76. http://dx.doi.org/10.1891/jnum.2005.13.1.65

\section{Extended English Abstract}

\section{Introduction}

The topic of wellness has emerged in the literature as a significant and positive concept among professional counselors. Perhaps one of the most well-known and researched wellness models was proposed by Myers, Sweeney, and Witmer (2000) who provided a comprehensive definition of the term wellness. Their definition is "wellness ia a way of life oriented toward optimal health and wellbeing, in which body, mind, and spirit are integrated by the individual to live life more fully within the human and natural community." They further described wellness as a complex group of learned behaviors and which can be taught and modified through education and counseling. Miller and Foster (2010) surveyed the many definitions of wellness that appeared in the literature and found that the various models of wellness that were appearing in the literature had common themes including choice, process, life-style, and characteristics of healthy individuals. In addition Miller and Foster concluded that although composed of a variety of factors wellness was essentially an integrated single concept with a focus on achieving balance and subjective appraisal. In 2010, the American Counseling Association (ACA), after reviewing much of the extent literature and achieving a consensus integrated the concept of wellness into its definition of Counseling (ACA, 2010). This position by the ACA recognizes the importance of wellness and its place as a fundamental topic and responsibility for practicing professional counselors. The importance of a well-founded model of wellness would seem to be an essential component for any counselor seeking to promote positive change among clients.

For any counselor seeking to integrate wellness into her/his counseling goals it is essential that the work be guided by a useful and comprehensive model which identifies essential dimensions of wellness along with instruments to make initial assessment which can serve as a baseline and standard for measuring change and progress. The Well-Star model was developed for use with a Turkish population and is composed of five dimensions: Physical, Social, Cognitive, Emotional, and Spiritual. The work described in this article documents the development of an 
Korkut Owen, F., Doğan, T., Demirbaş Çelik, N., \& Owen, D. W. (2016). İyilik Hali Yıldızı Ölçeği’nin geliştirilmesi. Journal of Human Sciences, 13(3), 5013-5031. doi:10.14687/ihs.v13i3.4130

assessment instrument for measuring each of these five dimensions and providing an overall total score that would represent an individual's state of wellness.

\section{Method}

\section{1. Participants}

The participants in this investigation were 545 university students representing three separate groups. The first of these groups was composed of 291 participants (119 female, 80 male, 2 unknown) and data were collected for the purpose of performing an exploratory factor analysis. The second group was composed of 156 (103 female, 52 male) and this data was used to perform a confirmatory factor analysis. The final group of 98 (85 females, 13 males) provided data that permitted assessment of concurrent validity and reliability.

\section{2. Scale Development Process}

After a careful review of the literature and initial pool of 103 items was generated. This pool was submitted for review by four professional counselor educators. Feedback from this review permitted the item pool to be reduced to 59 items.

\section{Findings and Discussion}

Exploratory factor analysis was performed on the data from Group 1 ( $n=291)$. If items were distributed across multiple factors and if their factor loadings were less than 0.30 the item were eliminated. Following 6 rotations a final structure of 24 items and five dimensions emerged. For the factor analysis the KMO value obtained was 0.84 and Barlett $\left(\chi^{2}=2058\right)$.

Confirmatory factor analysis was performed on Group $2(\mathrm{n}=156)$ to test goodness of fit whether the factor structure was acceptable $\left[\chi^{2}(239, \mathrm{~N}=156)=490.28, \mathrm{p}<0.01\right.$; CFI $=0.90$; IFI $=0.90$; SRMR $=0.085 ;$ RMSEA $=0.082]$. Following this analysis and confirmation of the five factor structure the title of Well-Star was selected to represent the instrument.

In an attempt to establish criterion related validity (concurrent type) the results of the Well-Star and the results of Health Promoting Lifestyle II (Walker \& Hill-Polerecky, 1996) which was adapted for Turkish by Bahar, Beşer, Gördes, Ersin and Kıssal (2008) when administered to Group 3 ( $\mathrm{n}=98$ ) were correlated. This analysis resulted in $\mathrm{r}=.76, \mathrm{p}<.0001)$ which was considered quite satisfactory.

Reliability was determined on two administrations (Group 1 and Group 3) by calculating Chronbach's Alpha. Alpha for Group 1 total score was 0.84 and for group 3 was 0.86. Alpha values for sub-dimensions ranged from $0.57-083$ for Group 1 and for Group 3 the range was from 0.57 to 0.79 . These results suggest that the instrument possess acceptable reliability.

\section{Conclusion and Suggestions}

In an attempt to design an assessment tool that reflects the Well-Star model a 24 item selfreport instrument was constructed and administered to a total of 545 university students. The results obtained from the three participant groups who completed the Well-Star suggest that this instrument possesses quite satisfactory validity and reliability. It is the opinion of the authors that this instrument could be a valuable tool for counselors working in university counseling centers and in community agencies settings and as a valuable adjunct for health promotion activities generally. Encouraging a wellness oriented lifestyle begins with an objective assessment of health related behaviors and the Well-Star model provides such a tool and a starting place from which to begin planning and making changes in client behaviors. 